\title{
KOLME HÄÄLIKUVÄLTE EKSITUSE MEHAANIKA
}

\author{
MATI HINT
}

\section{Sissejuhatus: prosoodia ja fonoloogia}

$\mathrm{K}$

arl Pajusalu on hiljuti avaldatud artiklis „Eesti keele sõnaprosoodia lõuna-läänemeresoome taustal” (Pajusalu 2014) käsitlenud läänemeresoome keelte lõunarühma keelte - ka eesti keele - prosoodiat mitmest vaatepunktist: läänemeresoome lõunarühma keelte hargnemine algläänemeresoomest, prosoodilised uuendused lõunaläänemeresoomes, toonivastandused liivi ja eesti keeles, prosoodiauuendusi mõjutanud häälikumuutused, rõhusiirded jm.

Pajusalu ülevaatlik artikkel jätab mulje, et selles on teadlikult kõrvale jäetud eesti keele prosoodia uurimise ja tõlgendamise ajajärk 1960-1990, mil valitsevaks meetodiks oli eksperimentaalfoneetika andmetele tuginev klassikaline fonoloogiline analüüs, perioodi teisel poolel ka uuemad teooriad (generatiivne grammatika, loomulik fonoloogia). Klassikalise fonoloogia erinevate koolkondade analüüsiprotseduurid annavad teadlasele suhteliselt kindlad kriteeriumid keele fonoloogilise mudeli konstrueerimiseks. Kuigi erinevate koolkondade - näiteks Praha (Nikolai Trubetzkoy) ja Ameerika deskriptivismiterminoloogiad ja ka analüüsiprotseduurid ei kattu täpselt, on nad olulises osas isomorfsed ja annavad fonoloogilise mudeli, mis peaks olema suuremate vasturääkivusteta (kui tõlgendamisel pole väga komistatud). Need meetodid on olnud tulemuslikud ka eesti keele uurimisel: eesti keele foneemiloendit ei saa populaarsetes ülevaatekäsitlusteski enam esitada selliselt, nagu näiteks Paul Ariste „Eesti keele foneetikas” (1953 jt trükid), mis kajastab kolme häälikuvälte teooria fonemiseerimise katset.

Muidugi võib kergitada analüüsiprotseduuride eneste verifitseerituse küsimuse, aga kuna Gödeli teoreem (formaalsed deduktiivsed süsteemid ei ole samal tasandil lõpuni vastuoludeta) kehtib ka meetodikindlas keeleteaduses, siis võib nendesse meetoditesse suhtuda nagu usaldusväärsesse antusse. Kuid ka fonoloogilise analüüsi protseduuride puhul kehtib nõue, et neid tuleb rakendada õigesti. Ei saa nõuda, et mutter kinnituks, kui teda keerata keermele vastupidises suunas.

Eesti keele prosoodia olemuse selgitamisel on fonoloogiateooriatel olnud suur positiivne osa. See roll pole lõppenud. Perioodil 1960-1990 loobuti eesti väldete olemuse selgitamisel üsna üldiselt kolme häälikuvälte ja häälikuühendite kahe välte teooriast ning pöörduti (tagasi) silbist ja silbi ehitusest lähtuvate tõlgenduste juurde (kuigi see ei kehti kõigi teema käsitlejate puhul võrdselt ja ühtmoodi).

Eesti keele häälikusüsteemi ja prosoodia uurimine on viimastel aastakümnetel klassikaliste fonoloogiateooriate metoodikatest kaugenenud, neid ei peeta nähtavasti enam nii tähtsaks, aga järjepidevuse kaotamine võib olla ka kavatsuslik: uuel põlvkonnal on näiliselt uuendusliku ja stagneerumata mõtteviisiga lihtsam alustada, kui ei olda kinni eelmise põlve teoreetilises 
mõtlemises. Võib ka olla, et uue põlvkonna uurijatel pole klassikaliste fonoloogiateooriate alal praktilist analüüsikogemust ega nende teooriate piisavat tundmist või siis peetakse humanitaarteaduse kohta suhteliselt hästi formaliseeritud fonoloogilise analüüsi protseduure aegunuks ning usaldatakse rohkem mõõtmistulemusi, mis võivad näida objektiivsemad kui opereerimine teoreetiliste konstruktidega ja analüüsialgoritmidega. Kuid mõõtmisega on nii, et enne mõõtmist tuleb küsida: mida mõõdetakse ja milleks? Klassikalise fonoloogia arusaamad on olulised ka foneetiliste mõõtmiste eesmärgipüstituses ja mõõtmisandmete tõlgendamisel.

Kindlat mõõtmiseusku oli kuulsaim eesti foneetik Ilse Lehiste. Tema jäi lõpuni kindlaks seisukohale, mille järgi näiteks esimese ja teise silbi vokaalide vahel mõõdetakse konsonandi ja konsonantühendi pikkust (kestust) ühesugustelt alustelt; kui näitesõnadeks on ema ja päästnud, siis mõõdetakse ja võrreldakse omakestusega silbialgulise konsonandi ning silbi- ja morfeemipiirilise konsonantühendi kestust ja arvatakse, et nii saadakse mudel, mis kirjeldab sõnaväldet (vt Lehiste 2000: 177). Võib olla, et kirjeldab, aga ei seleta. Lehiste seletab eesti prosoodiat ka aastal 1977 ja 2000 enam-vähem sama moodi, nagu seda tegi aastal 1879 Mihkel Veske: eesti keele häälikutel on kolm ja häälikuühenditel kaks kontrasteeruvat väldet. Lehiste uuendus seisneb selles, et ta tõstab esimese ja teise silbi kestuste suhte väldete tajumisel võtmetähtsusega tunnuseks, kuigi samas rõhutab sõnavormi teise silbi vokaali pikkuse sõltuvust esisilbi struktuurist (nt Lehiste 2000: 178).

Ka Pajusalu artiklis ei ole täit selgust mitme kriteeriumi osas, mis on prosoodiamudelite loomisel olulised: kas kvantiteet atributeeritakse segmendile või silbile, kas eristatakse kestusvastandusi võimaldavaid ja mittevõimaldavaid silbipositsioone, kas eristatakse häälikute omakestust ja kestusvastandusi, kas analüüsiüksusteks on võrdselt häälikud ja häälikuühendid (foneemid ja foneemijärjendid), mis metoodikaga määratakse esisilbi ja teise silbi kestuste suhe.

Lugematud kooliõpikud ja mitmele eesti keele õpetajate põlvkonnale peetud ülikooliloengud on kolme häälikuvälte ja häälikuühendite kahe välte arusaama juurutanud eesti keelega tegelejate teadvusse nii sügavalt, et sealt otsitakse seletust ka siis, kui selleks põhjust pole. Tänapäevaste fonoloogiateooriate seisukohalt on kolme häälikuvälte ja „liithäälikute” kahe välte teooria võimatu.

\section{Kolm väldet: kas segmentidel, silpidel või kõnetaktidel?}

Pajusalu artikli kõige küsitavamad allpeatükid kannavad pealkirju „Konsonandikeskne kolme välte vaheldus” ja „Vokaalikeskne kolme välte vaheldus”. Esimeses tõdetakse: „Vanimaks ternaarseks vastanduseks saab pidada lühikeste ja pikkade geminaatide lahknemise tõttu toimunud kolme konsonandikeskse sõnakvantiteedi teket" (Pajusalu 2014: 577). Klusiilgeminaatide lahknemine lühikesteks ja pikkadeks on läänemeresoome häälikuajaloos üldiselt aktsepteeritud seisukoht. Kolme fonoloogilist sõnakvantiteeti näitlikustab Pajusalu lühikese ja pika geminaadi vastanduse vaka : vakka abil, millele täiesti ilmselt tuleb täiendusena lisada vaga, teisiti ternaarset ahelat pole. (Seda näidete seeriat on ekspluateeritud läbi kogu eesti väldete kirjeldami- 
se ajaloo, juba alates Veskest.) Pajusalu näitesõnad pole fonoloogilises transkriptsioonis, seetõttu jääb lahtiseks, milles seisneb lühikese ja pika geminaadi fonoloogiline erinevus (sama küsimus konsonantühendite kohta), kas ülipikka vokaali tuleb käsitada foneemina jne. Neid küsimusi ei puudutatagi, fonoloogilist seisukohavõttu pole selles kontekstis peetud oluliseks.

Pajusalu ei väida otseselt, et eesti keeles esinevad häälikud kolmes fonoloogilises vältes, ta sõnastab oma väite sõnakvantiteedina. Kuid võib vist ütelda, et kõik, mida Pajusalu selles artiklis kirjutab, on sobitatav häälikute kolme fonoloogilise välte ning häälikuühendite kahe fonoloogilise välte teooriaga. Kirjutis läheb mööda silbivälte teooriast ning (üle)tähtsustab sõnavälte kujundamisel ja tajumisel kõnetakti eri silpide vahel valitsevaid kestussuhteid (kõnetakti kogustruktuuri).

Soome akadeemik Paavo Ravila esitas kogustruktuuri seisukoha 1961. aastal (Ravila 1961). Ka Lehiste on juba oma esimestes eesti kvantiteedi käsitlustes esitanud seisukoha, mille järgi sõnavälte kujundamisel ja äratundmisel on oluline esimese ja teise silbi kestuste suhe (Lehiste 1960: 63; 1966: 47-48). Tänapäeval korratakse seda üha sagedamini, küsitavustest küsimata. Teooriale on leitud nii põhjendusi kui ka nimetusi, mis avavad selle eri külgi: kahe esisilbi kestussuhe, jalg, (kõne)taktiisokroonia - kõik üsna selges mõttes Gestalt.

On asjatu arvata, et kolme häälikuvälte valeteooriaga on teaduslikes käsitlustes asi ühel pool. Müüt eesti keele justkui kogu üldkeeleteadust ümber lükkavast erilisusest on liiga armas. Kolme häälikuvälte juurde kinnijäänutele võib Pajusalu anda tuge näiteks järgmise lausega: „Kuigi konsonandikeskne ternaarne vältevastandus on maailma keeltes üliharuldane, on see läänemeresoome keeltes levinud laiemalt kui vokaalikeskne ternaarne vältevastandus" (Pajusalu 2014: 578). Igal juhul tähendaks kolmele häälikuvältele uute võimaluste andmine nende tulemuste kergekäelist kõrvalejätmist, mida eesti ja rahvusvaheline keeleteadus aastatel 1960-1990 on eesti kvantiteedi tõlgendamisel ja kvantiteedimudelite konstrueerimisel saavutanud. See oleks kahtlemata tagasilöök.

„Eesti ja liivi keeles on pika ja ülipika kestuse eristus laienenud geminaatide kõrval ka konsonantühenditele...." (Pajusalu 2014: 578). Sellinegi sõnastus on ühitatav „liht- ja liithäälikute” eristamisega 1930-1970-ndate kooliõpikutes ning Ariste foneemikontseptsiooniga, mille järgi eesti keeles on foneemideks ka konsonantühendid oma erinevates väldetes (nt Ariste 1953: 104).

Ootamatu on Pajusalu väide, et „konsonandid /f/ ja /š/ ei saagi kõnetakti tuumas [? - minu küsimärk, $M$. H.] esineda üksikkonsonandina, küll aga lühikese ja pika geminaadina...." (Pajusalu 2014: 578). See on fonoloogiaeelse eesti häälikuõpetuse seisukoht, millest loobuti juba 1960-ndatel, sest kirjatäht $\check{z}$ tähistab ortograafias lühikest (ühekordset) / ̌s/-foneemi. Mis puutub /f/-i, siis on raske hinnata, kui järjekindlalt ta erineb konsonantühendist $h v$; on neid, kes hääldavad raffas, ja neid, kes hääldavad pilahv. Need seigad ei puuduta siiski Pajusalu peateemat - ternaarsuse väidet.

Pajusalu võtab seisukoha ka Q2 saate 'te saate' ja Q3 saate 'saade : saate (gen)' vastandumise olemuse kohta. Häälikuvälte teooria nõuab igas silbitüübis nii vokaalse kui ka konsonantse osa välte defineerimist. Q2 saate ja Q3 saate silbitüübi puhul tuleb selles teoorias otsustada, kas vokaal ja geminaat on II või III vältes. Häälikuvälte teooria pole selle silbitüübi seletamisega hak- 
kama saanud: mõned vältega tegelejad määravad silbi vokaalse osa II vältesse ja klusiilgeminaadi või konsonantühendi III vältesse (harvemini vastupidi), sagedamini määratakse III vältesse mõlemad. Paar näidet:

EKG I/1 1963 lk 99-100 analüüsib loo`ka, saa`ta, söőkide kui II + III, kuid austama ja teotama on III + II; Lehiste 1966 lk 25 esitab kooki kui III + III, nagu ka Lehiste 2000 lk 177 saata ja päästnud.

Isegi häälikuvälte teooria üldtunnustatuse ajal oli väljaandeid, milles III-välteliseks märgiti kogu silp tervikuna, mitte konkreetne vokaal või konsonant. Sellise tähistusviisi juhtude hulgas on kõige tähelepanuväärsemad Elmar Muugi „Väike õigekeelsus-sõnaraamat” 1933 (nt saade : ‘saate, ka ‘komp`vek, ‘as`falt jne) ja seda järgiv „Väike õigekeelsuse sõnaraamat” 1953. Elmar Muuk kahtles häälikuvälte teoorias ja suutis selle kahtluse vormistada õigekeelsussõnaraamatus. Leho Võrk peab (saade :) saate tüüpi juhtudel IIIvälteliseks nii vokaali kui ka geminaatklusiili (Võrk 1966: 34), kuid aastaid hiljem annab sama vahekorra kohta seletuse, mille järgi II ja III välte erinevus selles silbitüübis tuleneb silbi kui terviku pikenemisest (II-vältelise silbi transformeerimisest III-välteliseks; Võrk 1972: 36-38). See on väga lähedal arusaamale, et II ja III välte erinevus on prosoodiline, silbi tasandi nähtus, mitte erinevus välteliselt erinevate segmentaalfoneemide või „liitfoneemide” valikus.

Silbivälte teoorias muutuvad need häälikuvälte dilemmad pseudoprobleemiks: II-välteline silp transformeeritakse prosoodia vahendite abil III-välteliseks (või vastupidi) silbi segmentaalkoostist muutmata, ja kõik. Transformeeritakse silp, mitte segment.

Pajusalu ütleb sellest silbitüübist kirjutades, et „sel juhul väljendub välteerinevus nii vokaali kui ka geminaadi pikkuses, kõnetakti tasandil ka rõhulise ja rõhutu silbi kestuste suhtes" (Pajusalu 2014: 579; viites ka Pärtel Lippus, Eeva Liina Asu, Pire Teras ja Tuuli Tuisk). Pajusalu sõnastus jätab tõlgendamisruumi: häälikuvälte teooria proponent näeks siin kinnitust, et II välte sõna pannakse kokku II-vältelisest vokaalist ja II-vältelisest geminaadist, III välte sõna aga vastavalt III-vältelistest segmentidest; silbivälte teooria võib Pajusalu sõnastust tõlgendada selliselt, et II- ja III-vältelise silbi erinevus avaldub kogu silbi tuumas ja lõpus, nii et II- ja III-vältelisel silbil on ühesugune foneemkoostis, vahe on silbi prosoodias, mitte segmentide erinevuses.

Tegelikult likvideerib häälikuvälte teooria prosoodia silbi tasandi nähtusena, sest häälikuvälte teoorial on kuskilt võtta nii II- kui ka III-vältelised vokaalid ja geminaadid, mis aheldatakse kokku, ja välde valmis. Sellise seletuse proovikiviks on paralleel „liithäälikutega”: II-välteline kausta (gen) ja III-välteline kausta (part) peaksid siis Veske kokku pandud healte hulgast või Ariste foneemiloendist saama valmiskujul II- ja III-vältelised „liithäälikud” või „liitfoneemid” $a u$ ja st, mis fonoloogia teoorias on otse mõttetult võimatu (vrd ka eespool toodud EKG I/1 näiteid austama ja teotama).

„Rõhulise silbi lühikese, pika ja ülipika vokaaliga sõnade ternaarne vältevaheldus [pigem vältevastandus $-M$. $H$.] on läänemeresoome keelealal välja kujunenud ainult eesti keelealal...." (Pajusalu 2014: 578). Edasises tõmbab Pajusalu paralleeli esisilbi pika vokaaliga ja diftongiga sõnade kõnetaktide vahele, mis on kõigiti loogiline, aga silpide ja kõnetakti silbijärjendi foneemkoostise küsimusest minnakse jälle mööda: jääb selgusetuks, missugune on pikkade ja ülipikkade vokaalide ning diftongide, aga ka konsonantühendite 
fonoloogiline staatus. Arvatavasti tuleb terminit „nn prosoodilised aktsendid” mõista samas tähenduses kui väldet (I, II, III), igatahes jagab Pajusalu seisukohta, mille järgi „,väldete esmaseks tunnuseks on esimese ja teise silbi kestuste erinev suhe" (Pajusalu 2014: 579). Kuidas selle esmase tunnuseni jõutakse, see jääb Pajusalu artiklis sama ebamääraseks kui paljudes varasemateski jalateooria esitustes.

\section{Silbivälte teooria vältimine}

Pajusalu viitekirjanduses (üle 60 nimetuse) puuduvad silbiprosoodia esiisa Ferdinand Johann Wiedemann ning Wiedemanni seletuse (Wiedemann 1875: 130-144) poole 1960-ndate alguses tagasi pöördunud Robert T. Harms ja Valter Tauli. Tiit-Rein Viitso on viitekirjanduses küll ulatuslikult esindatud, kuid mitte nende töödega, milles ta taasalgatas eesti kvantiteedi tõlgendamise silbi, mitte üksikhäälikuga seotud nähtusena. Puuduvad viited tänapäevase eesti eksperimentaalfoneetika rajajale Georg Liivile (esimese ja teise silbi kestussuhete esimesi mõõtjaid ja arvutajaid). Arvo Eek on koos Toomas Helbiga esindatud ühe ühiskirjutisega, kuid mitte Eegi viimase põhiteose „Eesti keele foneetika" I osaga (2008), milles Eek pöörab otsustavalt selja pikkade vokaalide kui iseseisvate foneemide seisukohale (Eek 2008: 56 jj, $125 \mathrm{jm}$ ). Eek oli üks jalateooria esitajaid, samas nägi ta selle teooria problemaatilisust: „Q3 sõna lühikeste ja Q2 sõna nn poolpikkade rõhuta vokaalide kestused on mõnikord minimaalselt erinevad" (Eek 2008: 104). Eek käsitles põhjalikult Q2 ja Q3 põhitoonierinevusi (Eek 2008: $57 \mathrm{jm}$ ), millele ka Pajusalu on pühendanud omaette alljaotuse. Mati Hindi paljudest silbivälte teooriat põhjendavatest kirjutistest pole kasutatud-viidatud ühtki.

Viiteid silbile Pajusalu artiklis leidub, aga silbiprosoodia puudub. Tõenäoselt on see läbikaalutud valik: esitada läänemeresoome keelte prosoodia panoraamne üldiseloomustus võimalikult üldistes mõistetes, konkreetselt ühtki eesti keele prosoodia teooriat eelisasendisse seadmata. Aga päris nii välja ei kuku, eelistatavaks kerkib kõnetakti kahe esimese silbi omavaheliste kestussuhetele rolli tähtsustamine - kõnetakti kogustruktuur ehk Gestalt (seda mõistet kasutamata). Muide ununeb taktide kogustruktuuri tähtsustajatel enamasti märkimata, et Wiedemann kirjeldas koos rõhuliste ja rõhuta silpidega ning rõhusilpide aktsentidega päris põhjalikult ka eesti keele takte (Wiedemann 1875: 130-144); see kirjeldus näitab usaldusväärselt, missugused rõhumudelid valitsesid temaaegses eesti keeles, on aga arvestatav ka tänapäeva keele taktide kujunemise mõistmisel.

Eesti keele väldete olemust esitatakse tänapäevases koolikirjanduses (valdavalt; alates Hindi keskkooliõpikust 1983), teaduslikena käsitatavates grammatikates ja eesti keele käsiraamatutes ning õigekeelsussõnaraamatutes silbiga seotud prosoodianähtusena, kuigi variante on mitmeid (sealhulgas silbiprosoodia sidumine kõnetakti struktuuriga). Pajusalu artikkel jääb selle arengu suhtes neutraalseks (to say the least). 


\section{Taktiisokroonia välte väljendajana: probleemid}

Pajusalu panustab taktiisokrooniale. Taktiisokroonia ehk kõnetaktide samapikkususe tendents tingib sõna esimese ja teise silbi pöördvõrdelise kestuse. Mõnelt murdealalt pärit inimesed „suudavad pikka ja ülipikka sõnakvantiteeti eristada ka üksnes esimese ja teise silbi kestussuhte põhjal" (toetumata rõhusilbi põhitooni erinevustele, vt Pajusalu 2014: 580 ning viidet Pajusalule ja Lippusele). Pajusalu kasutab ikka terminit sõnakvantiteet, aga - nagu jalateooria proponendid üldiselt - läheb temagi mööda teise silbi kestuse defineerimise raskustest.

Põhiküsimus on: kas sõnavälte tajumine sõltub enim rõhulise esisilbi vältest või esimese ja teise (rõhutu) silbi kestuste suhtest? Kahtlemata on taktiisokroonia mitmesilbiliste sõnade hääldamisel reaalne tendents, aga ükski esimese ja teise silbi kestussuhete analüüsija pole ammendavalt vastanud mitmele analüüsi ja teooria ülesehitamise seisukohast määrava tähtsusega küsimusele. Nii pika ajalooga teaduslikuna esitatava vaate puhul annab imestada, kui palju olulisi küsimusi on jäetud ebamääraseks. Selguse puudumine paljudes küsimustes ei suurenda usaldust jala- ja taktiisokroonia teooria vastu või kergitab koguni kahtluse, et selgus nendes küsimustes kõigutaks kogu jalateooriat.

1. Kuidas mõõdetakse teise (rõhutu) silbi kestust ja kuidas arvutatakse esimese (rõhulise) ja teise (rõhuta) silbi kestuste suhteid teise silbi erineva segmentaalse pikkuse korral, nt oma-omalt-omaks? Kui arvesse võtta terve silbi pikkus, siis on esmavältelistes sõnades, nt oma puhul, teine rõhutu silp (see tähendab vokaal) kestuselt enamasti pikem kui esimene rõhusilp, omalt ja omaks puhul on aga suhe vastupidine (ka jättes silbialgulise konsonandi mängust välja, kuna see silbi pikkust ei mõjuta). Kui arvesse võtta ainult teise silbi vokaali kestust, siis see varieerub nii murdeti kui ka kontekstis: oma võib olla nn poolpika teise silbi vokaaliga, omaks aga vaevalt.

2. Kuidas hinnatakse esimese ja teise silbi kestuste fonoloogilist relevantsust: kas mõlemad kestused on võrdselt fonoloogilised või on teine esimesest tingitud, st kas esisilbi välde ja kestus mõjutab teise silbi kestuslikku realisatsiooni (implikatiivne seos „kui ... siis”)? Kui teise silbi kestust käsitatakse sõltumatuna, nii et esisilp ei mõjuta teise silbi kestuslikku realisatsiooni, siis on teise silbi kestus fonoloogiline. Siis aga muutub küsitavaks kogu taktiisokroonia, sest tekib loogiline vastuolu (circulus vitiosus): taktiisokroonia eeldab, et teise silbi kestus balansseerib esimese silbi kestust, see aga on loogiliselt võimalik siis, kui teise silbi (või selle vokaali) realisatsioon sõltub esisilbi kestusest. Kui jälle nii, siis on teise silbi kestusel redundantse tunnuse staatus ning taktiisokrooniast kõneldes ei saa teise silbi kestust (kuidas seda siis kinnistes silpides ka ei mõõdetaks) pidada esisilbi prosoodilise kvantiteedi tajumisel esisilbi kestusega võrdseks tunnuseks. Redundantsetel tunnustel on kalduvus mitte esineda järjekindlalt ning see on omane ka teise silbi vokaali kõikuvale kestusele.

Silbikvantiteedi teooria ei eita silbiisokroonia osa välteerinevuste tajumisel, aga teise silbi vokaali kestus ei ole silbivälte teoorias iseseisva fonoloogilisusega, vaid sõltub esisilbi fonoloogilisest pikkusest ja teise silbi ehitusest. Edukaid teooriaid, mis põhjendaksid teise silbi vokaali poolpikkuse fonoloogilisust, pole. Juba Ariste (1953: 102) lükkas tagasi teise silbi rõhutu vokaali poolpikkuse iseseisva fonoloogilise kestusastmena (seda küll häälikuvälte teooria raames). 
Üks esimesi jalateooria esitajaid Lauri Posti defineeris teise silbi rõhutut poolpikka vokaali fonoloogiliselt pikana (eesmärgiks oli binarismi teooriasse mahtuv kolme välte seletus; Posti 1950), aga see on nii ilmses vastuolus foneetikaga, et Postile jääb selles küsimuses jalateooria elustaja ja binarismi taotleja au, tema jalateooria aga ei jäänud sellisel kujul jalgele.

Ka Lehiste ise on eitanud teise silbi vokaali (võimaliku) poolpikkuse fonoloogilisust: „Lahtise teise silbi foneetiline pikkus oleneb täiesti sellele eelneva esimese silbi vältest....” (Lehiste 1997: 34). „Järgsilpide kestuses on aga süstemaatilisi - ning ennustatavaid - erinevusi. Tingivaks teguriks on eelneva silbi struktuur. Teise silbi vokaalide puhul on selleks esimese silbi struktuur" (Lehiste 2000: 178). Mis fonoloogilisusest sellisel puhul saab rääkida?

3. Taktiisokrooniat käsitledes tuuakse enamasti näited ideaalmaailmast, milles eesti sõnavormid on kahesilbilised ja lahtise teise silbiga. Aga on ju veel ka ühe- ja kolmesilbilised kõnetaktid ning kolmesilbilistes kõnetaktides võib teise ja kolmanda silbi ehituses olla suuri segmentaalseid erinevusi, mis mõjutavad esisilbi ja teise silbi kestuste suhteid. Ideaalse näitematerjali eelistamine sarnaneb kolme häälikuvälte teooria esitustega, mis piirduvad nn lihthäälikute seeriatega ( $k o l i-k o o l i-k$ 'ooli ja koli - kolli - ko`lli) ning väldivad diftongidega ja konsonantühenditega silpide fonemiseerimise probleeme. See on otseselt teooria verifitseerimise ja falsifitseerimise probleem. On selge, et häälikuvälte teooria on eesti häälikusüsteemi fonoloogilise mudelina verifitseeritav üksnes valitud näitematerjali põhjal ning kergesti falsifitseeritav vähegi ulatuslikuma näitematerjali kaasamise korral; tuleb küsida: kuidas sellest seisukohast on lugu taktiisokroonia teooriaga?

\section{Ternaarsete vastanduste kontekst}

Kõige raskem küsimus Pajusalu kolme sõnavälte vastandustes on konteksti, ümbruse defineerimine: missuguses häälikuümbruses, missuguses silbipositsioonis annavad näiteks vastandatavad klusiilipikkused kolm erinevat sõnaväldet, mille aluseks on Pajusalu (2014: 577) sõnastuses „konsonandikeskne ternaarne vastandus"?

Mis tahes fonoloogiateoorias tuleb häälikute (segmentide) diferentseerivat, tähendust eristavat võimet tõestada ühesuguses kontekstis, samases häälikuümbruses, nii-öelda samas raamis. Kahjuks on seda raami võimalik tõlgendada mitmeti. Lehiste näiteks defineerib mitmes töös konsonantse ainese kvantiteeti raamis, milleks on positsioon esimese ja teise silbi vokaalide vahel. Nii satuvad konsonantse ainesena konsonantideks nii üksikkonsonandid ja geminaadid kui ka konsonantühendid, isegi morfeemipiirilised konsonantühendid (päästnud). Lehiste välte kaardistamisreeglite tabeli teine ja kolmas veerg esitab sisuliselt 1920-1980-ndate kooliõpikutes välte määramisel kasutatud sisehäälikuid (mõiste sisemised healed tuleb Veskelt; vt Veske 1879: 60 jm). See ongi päris traditsiooniline häälikuvälte teooria, milles figureerivad ka liht- ja liithäälikud. Nagu eespool viidatud, viib katse seda mõtteviisi fonemiseerida Ariste foneemiloendini, milles diftongidel ja konsonantühenditel ning nende erinevatel kestusastmetel on foneemi staatus. Tõlgendus, milles ühed foneemid koosnevad teistest foneemidest, ei ole mis tahes fonoloogiateoorias aktsepteeritav, isegi eesti keele puhul mitte. 
Välte kaardistamisreeglid*

\begin{tabular}{|c|c|c|c|c|}
\hline $\begin{array}{l}\text { Esimese } \\
\text { silbi } \\
\text { välde }\end{array}$ & $\begin{array}{l}\text { Esimese } \\
\text { silbi } \\
\text { vokaal }\end{array}$ & $\begin{array}{l}\text { Vokaalide- } \\
\text { vaheline } \\
\text { konsonant või } \\
\text { konsonant } \\
\text { ühend }\end{array}$ & $\begin{array}{l}\text { Skemaati- } \\
\text { line } \\
\text { kujutamine }\end{array}$ & Näited \\
\hline 1. lühike & $\begin{array}{l}\text { lühike } \\
\text { lühike }\end{array}$ & $\begin{array}{l}\text { lühike } \\
\text { pikk }\end{array}$ & $\begin{array}{l}1+1 \\
1+2\end{array}$ & $\begin{array}{l}\text { ema, sada } \\
\text { kata (2. isik, imperatiiv) } \\
\text { kanna (2. isik, imperatiiv) }\end{array}$ \\
\hline 2. pikk & $\begin{array}{l}\text { pikk } \\
\text { pikk } \\
\text { lühike }\end{array}$ & $\begin{array}{l}\text { lühike } \\
\text { pikk } \\
\text { ülipikk }\end{array}$ & $\begin{array}{l}2+1 \\
2+2 \\
1+3\end{array}$ & $\begin{array}{l}\text { saada ( } 2 \text {. isik, imperatiiv) } \\
\text { saate ( } 2 \text {. isik, mitm. olevik) } \\
\text { katta, kanda }\end{array}$ \\
\hline 3. ülipikk & $\begin{array}{l}\text { ülipikk } \\
\text { ülipikk }\end{array}$ & $\begin{array}{l}\text { lühike } \\
\text { ülipikk }\end{array}$ & $\begin{array}{l}3+1 \\
3+3\end{array}$ & $\begin{array}{l}\text { saada (infinitiiv) } \\
\text { saata, päästnud (isikul. tm. } \\
\text { min. kesksõna) }\end{array}$ \\
\hline
\end{tabular}

* Lehiste 2000a: 177 = Lehiste 1977: tabel 1.

Traditsioonilises sisehäälikute kontseptsioonis ei arvata sisehäälikute hulka sõnaalgulist konsonanti või konsonantühendit, ja väga õigesti, sest see ei mõjuta silbi kvantiteeti (ega järelikult ka sõnaväldet). Sama kehtib teise silbi või mis tahes silbialgulise konsonandi kohta - see ei mõjuta silbi prosoodilist pikkust. Traditsioonilistel sisehäälikutel oleks mingi mõte klausliga, mis välistab teise silbi algulise konsonandi sõnavälte määramispiirkonnast (aga sellel on eesti ortograafiast tulenevalt oma raskused: Juku õpib ei avalda geminaati ilma lisaõppuseta). Sõnaalguline konsonant on lihtsalt konsonant, millel on omakestus, mida pole mõtet nimetada lühikeseks, pikaks või ülipikaks, sest need on kõik kontrasteeruvate kestusastmete väljendamise terminid, millel sõna alguses pole sisu.

Arvo Eegi definitsioon ütleb: „Häälikul ei ole väldet, tal on omakestus” (Eek 2008: 64). Kunagistes kooli- ja teaduslikegi taotlustega grammatikates esitatud nõue määrata eesti keele sõnavormides nii rõhulistes kui ka rõhututes silpides kõigi häälikute ja häälikuühendite välted, saab mingisugusegi mõtte ainult sellise teooria raames, mis kujutleb eesti keele häälikusüsteemi foneemirepertuaari hiigelsuure laona, millest võetakse erineva vältega häälikuid ja häälikuühendeid (liht- ja liithäälikuid, resp. liht- ja liitfoneeme, kui liitfoneemi mõiste oleks võimalik), et nendest klotsidena kokku panna sõnavorm (nt EKG I/1: 97-98 jm). Välde on siis liht- ja liithäälikute inherentsete kestuste summa, mitte prosoodiline, silbi või kõnetaktiga seotud nähtus. Sellise „teooriaga” tuleks ükskord hüvasti jätta.

Kindlasti ei järgi Pajusalu häälikuvälte teooria foneemikontseptsiooni selle ekstreemses võimatuses - Pajusalu rõhutab vältetajus kõnetakti kogustruktuuri olulisust, mis häälikuvälte teoorias pole oluline. Kuid konsonandikeskne kolme välte vaheldus on Pajusalul üles ehitatud siiski silbialgulise üksikkonsonandi ning lühikese ja pika geminaadi vastandumisele (Pajusalul vaheldusele) esisilbi vokaali ja teise silbi vokaali vahelises positsioonis. Ternaarses vastanduses osalevad niiviisi teise silbi algulise üksikkonsonandi omakestus 
ning silbipiirilised geminaadid - lühike ja pikk. Omakestus on nagunii hääliku inherentne omadus, kui nüüd ka geminaatide kahesugune pikkus on nende inherentne omadus (nad on nii-öelda valmistooted), siis kestusega seotud prosoodilisi vahendeid pika ja ülipika silbi eristamiseks ei vajata. Prosoodiat on siin siis ainult sedavõrd, et arvestatakse kõnetakti kahe esisilbi kestuste suhetega (kõnetaktiprosoodia). Fonoloog ei saaks ütelda, et mingis keeles x on konsonandid lühikesed, kui selles keeles puuduvad pikad konsonandid; sel puhul esitatakse fonoloogilise süsteemi iseloomustuses konsonandid ja nende esinemistingimused ja nenditakse, et konsonantide pikkus- või kestuskorrelatsioon puudub. Eesti keele puhul tuleb ütelda, et silbialgulises positsioonis konsonantide kestuskorrelatsioon puudub. Konsonandikeskseid kolme välte vastandusi saab konstrueerida üksnes nii, et vastandustesse tõmmatakse kaasa ka silbialguline konsonant, mis tegelikult kestusvastandustes ei saagi osaleda. Lehiste välte kaardistamisreeglid põhinevad sellisel mehaanikal, eespool tsiteeritud tabel näitab seda selgelt: $k a d a-1$ ehk lühike, kata - 2 ehk pikk, $k a t t a-3$ ehk ülipikk. Näib, et Pajusalu seisukohad on lähedased või identsed Lehiste omadega. Silbivälte teooria eitab sellist tõlgendust, mis on vastuolus fonoloogia põhitõdedega.

Kuna teise silbi alguline konsonant ei võta osa sõna välte kujundamisest, siis ei representeeri Lehiste esmavälteliste sõnade näitesõnad ema ja sada (vt tabelit eespool) mitte mudelit $1+1=1$ (lühike vokaal + lühike konsonant annab I välte), vaid $1=1$ (esisilp on lühike ja lahtine). Kui II välte puhul on silbituumaks pikk vokaal (kuidas seda siis fonoloogiliselt ka ei tõlgendataks), siis ei vajata II välte saamiseks valemit $2+1=2($ saada $)$, vaid $2=2$ (teise silbi alguline üksikkonsonant ei mõjuta väldet, ta on vajalik selleks, et sõnas oleks kaks silpi); III välte puhul ei vajata valemit $3+1=3$ (s`aada), vaid $3=3$ (kui eeldada, et ülipikad vokaalid on fonoloogilises süsteemis olemas; silbivälte teooria seda seisukohta ei jaga; silbivälte teoorias on III välde või II ja III välte erinevus rõhulise silbi prosoodiline lisatunnus).

Väärkujutlus, et teise silbi algulisel konsonandil on roll sõna välte kujundamises, tuleneb traditsioonilisest sisehäälikute määramise reeglist ning soovist näha esimese ja teise silbi vokaalide vahel kolmes vältes esinevate konsonantide vastandust. See ei ole fonoloogiliselt adekvaatne tõlgendus.

\section{Geminaadid ja konsonantühendid esimese ja teise silbi piiril}

Kui geminaadid ja konsonantühendid esinevad esimese ja teise (rõhulise ja rõhutu) silbi vokaalide vahel, siis satub nende järelliige (resp. viimane konsonant) samasse positsiooni, kus esineb I-vältelise sõna teise silbi alguline konsonant - tal pole rõhutu silbi alguskonsonandina välte kujundamisel mingit osa. I vältest eristuva II või III välte kujundab esisilbi kinnisus (järgnevates näidetes jäetakse palatalisatsioon märkimata): val-li ja val-mi, kas-si ja kas-ti, vak-(k)a ja vak-sa, kot-(t)a ja ot-sa.

Neis kõigis on ühesuguse ehitusega esisilp (paarikaupa veel ühesugusem). Kui nad kõik on II välte sõnad, siis nende II välde ei olene sellest, kas kahe silbi piiril on geminaat või konsonantühend, sest nii konsonantühendi kui ka geminaadi järelliige satuvad positsiooni, kus nad ei mõjuta ei esisilbi ega ka teise silbi prosoodilist pikkust (nullmõju, zero, Ø). Esisilp on pikk silp ka ilma 
teise silbi algulise konsonandita, sõnavormi teine silp on vajalik selleks, et II ja III välte vastandus oleks võimalik, aga see vastandusvõimalus on rõhulises silbis.

III välte puhul peab esisilbi lõppu jääv geminaadi või konsonantühendi esiliige andma sõnale III välte (Pajusalu ja jala- või taktiisokroonia teoreetikute arvates koos kogu kõnetakti struktuuriga; silbivälte teooria seisukohalt määrab III-välteline esisilp redundantsete tunnuste väljendumise ja on seega kõnetakti III-vältelisuseks fonoloogiliselt piisav):

va`l-li ja va`l-mi, ka`s-si ja ka`s-ti, va`k-ka ja va`k-sa, ko`t-ta ja o`t-sa.

I välte erinevus II ja III vältest tuleneb sõna esisilbi segmentaalsest pikkusest: I välde tähendab lühikest lahtist rõhusilpi, II ja III välde tähendavad segmentaalselt pikka (kas kinnist või lahtist) rõhusilpi. Silbivälte teoorias ei tulene II ja III välte erinevus segmentaalsest (häälikkoostise) erinevusest, vaid nende vastandus on prosoodiline, nii et II- ja III-vältelised sõnad võivad olla ühesuguse segmentaalkoostisega. Muuseas kajastab seda ka eesti ortograafia, mis (klusiilid välja arvatud) annab kirjatähed segmentidele ja mitte prosoodilistele tunnustele.

III-välteliste sõnavormide kirjaviis äsjastes näidetes võib siiski olla eksitav: võib jääda mulje, et prosoodilise lisatunnusega (häälikuvälte tõlgenduses III vältes) on kas konsonant, geminaat või konsonantühend. Tegelikult lisandub prosoodilise kvantiteedi lisatunnus esisilbile, ning silbistruktuuri reeglid määravad, kus ja kuidas see lisanduv prosoodilist vastandumist võimaldav lisatunnus avaldub (vt Hint 2001). Äsjaste näidete silbitüübis saab see prosoodiline transformatsioon avalduda silbilõpulises konsonandis, aga sellest hoolimata on õigem käsitada prosoodilist lisatunnust silbi tunnusena:

`val-li ja `val-mi, `kas-si ja `kas-ti, `vak-ka ja `vak-sa, `kot-ta ja `ot-sa.

Kolm traditsioonilist väldet on silbitatud näidetena sellised:

\begin{tabular}{|c|c|c|c|c|}
\hline$\left[\begin{array}{cc}{[} & k o-l i \\
\text { II } & k o l-l i \\
& \end{array}\right.$ & $\begin{array}{l}\text { ko-le } \\
\text { kol-me }\end{array}$ & $\begin{array}{l}\text { va-ga / vaka / } \\
\text { vak-(k)a } \\
\text { vak-ka }\end{array}$ & $\begin{array}{l}v a-g a \\
v a k-s a\end{array}$ & $\begin{array}{l}\text { ko-da / kota / } \\
\text { kot- }(t) a\end{array}$ \\
\hline & kol-me & val & & \\
\hline
\end{tabular}

\section{Keeleajalooline kommentaar}

Läänemeresoome keelte astmevahelduse kujunemise esmased hääldusnihked ei ole kõige ootuspärasem keeleajalooliste häälikumuutuste rida just seetõttu, et silbialgulise konsonandi positsioonis on mõni konsonantide klass (näiteks nasaalid) häälikumuutustele suhteliselt immuunne. Klusiilide muutumine selles positsioonis pole siiski nii haruldane (näiteks palataliseerumine око очи, отеи - отче). Astmevahelduse algusfaasis tulebki nõrga astme tekkimiseks oletada teise silbi algulise klusiili häälduse muutumist või nõrgenemist. Seda võib käsitada vastuargumendina silbialgulise konsonandi omakestuse seisukohale. Vastuolu oli siiski ainult näiline. 
Silbipiiriliste klusiilgeminaatide lahknemine lühikesteks ja pikkadeks on läänemeresoome häälikuajaloos üldiselt aktsepteeritud seisukoht (ka Pajusalu 2014: 577). Silbipiiriliste konsonantühendite silbialgulise järelliikme häälikukvaliteedi muutumine (assimileerumine, teisenemine, kadu) näitab, et muutus tabas klusiili just silbialgulises positsioonis:

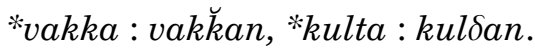

Fonoloogia seisukohalt on silbialguline lühenenud või spirantiseerunud klusiil ikkagi ainult vastavalt foneemide $/ \mathrm{k} / \mathrm{ja} / \mathrm{t} / \mathrm{kontekstist}$ tingitud variant, kusjuures kontekst (ümbrus) on defineeritud silbi terminites: lahtise silbi alguses on nii-öelda normaalne klusiil, kinnise silbi alguses lühenenud või häälduselt muutunud klusiilivariant. Fonoloogilist muutust toimunud pole. Fonoloogiline muutus toimub 1) siis, kui ümbrus muutub ühesuguseks, nii et tavaline ja lühenenud geminaat esinevad mõlemad näiteks lahtise teise silbiga sõnavormides, või 2) siis, kui häälduslikult muutunud klusiil langeb kokku mõne teise foneemi hääldusega või kaob sootuks: kulda: kulla(n) puhul oleks veider väita, et silbialguline [l] on /t/-foneemi nõrk aste ning et on kahesuguseid ///-foneeme - päris-///-foneemid ja /t/-foneemi nõrgad vasted. Samamoodi oleks veider otsida tugevaastmelise tüvevariandi rida/t/-foneemi nõrka vastet nõrga tüvevariandi rea silbipiiris (esialgu kahesilbiline $r e-a$, hiljem kadus silbipiirgi). Häälikuajaloolised muutused seletavad keele fonoloogilise süsteemi kujunemise järjestikuseid ajajärke: fonoloogilise süsteemi restruktureerimisel asendab muutunud fonoloogiline süsteem endise süsteemi, keeleajalooline häälikumuutus on uues süsteemis morfofonoloogiliseks (flektiivseks) vahelduseks.

Siin ongi üks suur erinevus häälikuajaloole üles ehitatud grammatikate ja fonoloogilisele analüüsile üles ehitatud grammatikate vahel: esimesed käsitavad (ka eesti keele kooligrammatikad kuni aastani 1983) astmevaheldust foneetika nähtusena, teised flektiivse morfoloogia nähtusena (morfofonoloogiliste vahelduste süsteemina).

\section{Järeldused}

1. Silbi segmentaalne ja prosoodiline pikkus sõltub silbituumast ja silbilõpust. I-vältelistes sõnades silbilõpp puudub ning lühikesele vokaalile järgnev konsonant on teise silbi alguseks, kus ta ei mõjuta esisilbi väldet; see konsonant kestusvastandustes ei osale, tal on ainult omakestus. Konsonandikeskset kolme välte vaheldust ei ole olemas, see, mida sellisena demonstreeritakse, on saadud mittevõrreldavate nähtuste kokkupanekul: teise silbi algulist ainult omakestust omavat konsonanti võrreldakse II ja III välte sõnades geminaatidega, mille esiliige asub silbilõpulisena kestuskorrelatsiooni positsioonis. Selline võrdlemine ei ole fonoloogia teooria seisukohalt korrektne: vastandatakse silbilõpu puudumist (nulli) ning lühikese ja pika geminaadi esiliiget silbi lõpuna. Esmavältelistes sõnades on esisilbi prosoodilisteks tunnusteks rõhulisus ning silbi segmentaalne lühidus; võib-olla on redundantse (esisilbist sõltuva) tunnusena oma (ebajärjekindel) roll ka sõna kogustruktuuril kahe esisilbi kestuste suhtena. 
2. Ka II-vältelistes sõnades ei mängi teise silbi alguline konsonant esisilbi pikkuse ja sõnavälte seisukohalt rolli, kuid see konsonant tagab sõnavormi mitmesilbilisuse. Kas esisilbi ja teise silbi vokaalide vahel on geminaat või konsonantühend - vahet pole. Teise silbi algulisel konsonandil, olgu ta geminaadi või konsonantühendi järelliige, on ikkagi üksnes omakestus. Tabelinäidetes jäävad esisilbi väldet kujundama lühike vokaal silbituumana ja konsonant silbilõpuna (keerulisema silbistruktuuriga sõnades on võimalused mitmekesisemad nii II kui ka III välte sõnades, vt Hint 2001). Kas see konsonant on geminaadi või konsonantühendi esiliige - vahet pole. II-vältelistes sõnades on esisilbi prosoodilisteks tunnusteks rõhulisus ning segmentaalne silbipikkus; võib-olla kuulub esisilbi ja teise silbi kestuste tasakaalustatud suhe redundantse (esisilbist sõltuva) tunnusena välte väljendamise ja tajumise tunnuste hulka.

3. III-vältelistel sõnadel on II-vältelistega võrreldes see eripära, et esisilbi segmentaalsele pikkusele lisandub prosoodiline kvantiteet, mis näitesõnades realiseerub silbilõpulise konsonandi lisakvantiteedina. Rõhusilbi II ja III välte erinevus on eesti keele fonoloogilises süsteemis ainus otseselt prosoodiline kvantiteedikorrelatsioon, mis on relevantne ja ei ole tuletatav teistest tunnustest.

4. Selleks et saada adekvaatne pilt eesti keele sõnavormide esisilbi välte kujunemisest, tuleb äsjastes näidetes teise silbi alguline konsonant välte „kaardistamisreeglitest” (Lehiste termin) välja arvata. Vokaalse silbituuma ja konsonantse silbilõpu roll esisilbi välte kujunemisel on siis järgmine:

I välde: 1 (vokaal) $+\varnothing$ (konsonant) (vrd Lehistel $1+1)$

II välde: 1 (vokaal) +1 (konsonant) (vrd Lehistel $1+2)$

III välde: 1 (vokaal) $+1+1$ (konsonant) (vrd Lehistel $1+3)$

III välte $(1+1)$ on Lehiste „kaardistamisreeglites” ülipika geminaadi või konsonantühendi esiliige, millele teise silbi algusena liitub veel üks konsonandiüksus (kokku üks koond-3); silbivälte teoorias tähendab (1 + 1) konsonanti + toodud näidetes silbilõpulist konsonanti pikendavat prosoodilist silbikvantiteeti; võiks kirjutada ka 1 (vokaal) + 1 (konsonant) + prQ.

Vokaalikeskne kolme välte vastandus on silbivälte teoorias järgmine:

I välde: 1 (vokaal) $+\varnothing$ (teise silbi alguline konsonant) (vrd Lehistel $1+1)$

II välde: $1+1$ või 2 (vokaal) $+\varnothing$ (konsonant) (vrd Lehistel $2+1$ )

III välde: $1+1$ või 2 (vokaal) $+1+\varnothing$ (konsonant) (vrd Lehistel $3+1)$

Kas II välte pikka vokaalhäälikut tõlgendatakse fonoloogiliselt kahe vokaali järjendina $1+1$ (Hint kõigis probleemikäsitlustes, aga ka Eek väga otsustavalt 2008: 54-57) või lühikesele vokaalile vastanduva pika vokaalfoneemina 2 , see sõltub sellest, kas foneemiinventaris nähakse ainult 9 vokaali või lühikesi ja pikki vokaale eraldi seeriatena. III välte ülipikka vokaalhäälikut tõlgendab häälikuvälte teooria ülipika vokaalfoneemina (3), silbivälte teooria kahekordse $(1+1)$ või pika $(2)$ vokaalfoneemina + prosoodiline silbikvantiteet $(1+1+\operatorname{prQ}+\varnothing$ või $2+\operatorname{prQ}+\varnothing)$. 


\section{Eesti prosoodia laiemas kontekstis}

Pajusalu vaatleb võrdlevalt kogu läänemeresoome lõunarühma keelte prosoodiat, mis on mõistagi väga kiiduväärt. Problemaatilisem on see, missugune arusaam eesti kvantiteedi olemusest resp. tõlgendusest selle artikli põhjal kujuneb.

Pajusalu kirjutises saab silp välte segmentidelt (nii ka Lehistel) ja mitte vastupidi, nagu silbivälte teoorias, kus silbil on välde ja segmendid realiseeruvad vastavuses nende võimalustega, mille määravad silbivälde ja segmendi positsioon silbis (Hint 2001). Kui välted tuletada segmentide inherentsest kvantiteedist, siis kvantiteediprosoodiat selle sõna otseses tähenduses eesti keeles pole, küll aga oleks eesti keeles siis veidralt suur hulk erineva kvantiteediga segmente ja n-ö komplekssegmente (diftonge ja konsonantühendeid häälikute funktsioonis).

Läänemeresoome lõunarühma keelte prosoodiliste erijoonte kokkuvõtvas tabelis silbikvantiteet üldistusena puudub, kuigi silbikvantiteedi erijuhud lühikeste geminaatidena ja vokaalikeskse vältevaheldusena on seal esikohal (Pajusalu 2014: 584). Pajusalu märgib tekstis küll geminaatidest ja pikkadest vokaalidest alanud pika ja ülipika kestuse vastandamise laienemist eesti keeles, aga ta käsitleb kestusvastanduste laienemist kui konsonantühendite ja diftongidega seotud nähtust (Pajusalu 2014: 578-579). Tänapäeva seisukohalt on siiski tegemist pika silbiga seotud prosoodianähtusega. Silbikvantiteetide vastandamine on tänapäeva põhjaeesti ja lõunaeesti keele fonoloogilistes süsteemides ühtlustunud erineva häälikulise ehitusega pikkadele silpidele süsteemselt, kuigi keeleajalooline protsess selle nähtuse kujunemisel arvatavasti algas klusiilgeminaatidest (ka Hint 1986) ning erinevates silbitüüpides ja erinevatel murdealadel võivad selle vastanduse foneetilised mehhanismid erineda.

Tõenäoselt on teiste läänemeresoome lõunarühma keelte prosoodiatõlgendused mõjutanud Pajusalu esitama ka eesti keel(t)e prosoodiat samadelt alustelt, mis on käepärane näiteks liivi keele prosoodiat käsitledes. Pretendeerimata Pajusalu hinnangus vähese prosoodilise eripäraga vadja keele ja suure prosoodilise eripäraga liivi keele prosoodia tundmisele, võib siiski küsida: kas ehk ei tuleks ka nende keelte prosoodia analüüsis keskenduda silbile kui prosoodia avaldumise põhiüksusele? Tulenevad ju prosoodia muutused enamasti häälikumuutustest, mida defineeritakse silbi terminites. Samasugust paradigmamuutust - keskendumist silbile ka tänapäevastes keeltes - võiks üritada saami keelte prosoodia võrdlemisel liivi, lõunaeesti ja põhjaeesti keele prosoodiaga.

Liht- ja liithäälikute teooriast pärinevatele ettekujutustele toetumine ainult ähmastab eesti prosoodia olemuse mõistmist. Häälikuvälte teooria on falsifitseeritav juba paari analüüsisammuga. Kui küsida, kas pikkade vokaalidega samu silbipositsioone täitvad diftongid on samasugused fonoloogilised üksused nagu pikad ja ülipikad vokaalid, siis vastab häälikuvälte teooria: jah. Siis on ka diftongid oma kahes vältes (II ja III) sama moodi foneemid nagu pikk ja ülipikk vokaal.

Silbivälte teooria vastab sellele küsimusele teistmoodi: pikad vokaalid on sama moodi kahe vokaali järjendid nagu diftongid (ka Eek 2008: 56-57). Kui küsida, kas esisilbi ja teise silbi vokaali vahelised konsonantühendid on samasugused fonoloogilised üksused kui geminaatkonsonandid, siis vastab häälikuvälte teooria: jah. Silbivälte teooria vastab sellele küsimusele vastupidiselt: 
ei - geminaadid on sama moodi kahe konsonandi järjendid nagu konsonantühendid.

Häälikuvälte teooria annab vastused, mis on fonoloogia teoorias võimatud: ühed foneemid koosnevad teistest foneemidest. Silbivälte teooria seletus on vastupidine: pikad vokaalid ja konsonantgeminaadid pannakse kokku vokaalvõi konsonantfoneemidest sama moodi nagu diftongid ja konsonantühendid.

Häälikuvälte teoorias järeldatakse: kui pikk $\bar{o}$ ja ülipikk $\hat{o}$ on foneemid, siis on ka diftongid oma kahes erinevas kestuses foneemid. Silbivälte teoorias pööratakse see pea pealt jalgele: kui diftong on kahe foneemi järjend, siis on ka pikka vokaali mõistlik tõlgendada ühte silbituuma kuuluva vokaalijärjendina (sama - mutatis mutandis - geminaatide ja konsonantühendite osas):

$$
\begin{array}{r}
k|o| l|i-k| \bar{o}|l| i-k|\hat{o}| l \mid i \\
-k \mid \text { oe }|r| a-k \mid \text { oe }|r| a .
\end{array}
$$

Eesti keele prosoodia tõlgendamine silbivälte teooria raamis on nii palju edenenud, et ka õigekeelsussõnaraamatud märgivad juba poolteist aastakümmet jälle silbiväldet, nagu tegi Muuk oma „Väikeses õigekeelsus-sõnaraamatus" juba aastal 1933. Loodetavasti tähendab see lõplikku loobumist kolme häälikuvälte teooria ummikust.

Teaduslikkust taotlevad eesti keele tänapäevased käsitlused ei tihka enam esitada häälikuvälte teooriat, kuid selle teooria psühholoogiline mõju pole kadunud ei mõtlemises ega terminite kasutamises. Teinekord avaldub vana armsa müüdi mõju ootamatuteski seostes.

\section{Kirjandus}

A r i s t e, Paul 1953. Eesti keele foneetika. Tallinn: Eesti Riiklik Kirjastus.

E e k, Arvo 2008. Eesti keele foneetika I. Tallinna Tehnikaülikool. Küberneetika Instituut. Tallinn: Tallinna Tehnikaülikooli Kirjastus.

EKG = Eesti keele grammatika I. 1. vihik: Häälikuõpetus ja ortograafia. Koostanud P. Ariste, A. Kask, A. Kiindok jt. Tartu: Tartu Riiklik Ülikool, 1963.

H i n t, Mati 1983. Eesti keele õpik IX klassile. Tallinn: Valgus.

$\mathrm{H}$ i n t, Mati 1986. Viron prosodisen systeemin perusluonteesta. - Virittäjä, nr 4, lk 428-440; ettekanne FU-kongressil 1985 Sõktõvkaris. Muutmata uustrükk raamatus: M. Hint, Eesti keele astmevahelduse ja prosoodiasüsteemi tüpoloogilised probleemid. Tallinn-Helsinki, 1997, lk 181-193.

H i n t, Mati 2001. Prosoodiaväitlustes läbimurdeta II. III-vältelise silbi struktuur. - Keel ja Kirjandus, nr 5, lk 324-339.

Lehiste, Ilse 1960. Segmental and syllabic quantity in Estonian. - American Studies in Uralic Linguistics. (Indiana University publications, Uralic and Altaic Series 1.) Bloomington: Indiana University, lk 21-82.

Lehiste, Ilse 1966. Consonant Quantity and Phonological Units in Estonian. (Indiana University publications, Uralic and Altaic Series 65.) Bloomington: Indiana University, The Hague: Mouton.

Lehiste, Ilse 1977. Quantity in Estonian language and poetry. - Journal of Baltic Studies, nr 2, lk 130-141. [Eesti keeles vt Lehiste 2000.]

Lehiste, Ilse 1997. Search for phonetic correlates in Estonian prosody. Estonian Prosody: Papers from a Symposium. Proceedings of the International Symposium on Estonian Prosody. Tallinn, Estonia, October 29-30, 1996. Toim I. Lehiste, Jaan Ross. Tallinn: Institute of Estonian Language, lk 11-35. 
L e h i s t e, Ilse 2000. Välde eesti keeles ja luules. - I. Lehiste, Keel kirjanduses.

Koost Jaan Ross. (Eesti mõttelugu 36.) Tartu: Ilmamaa, lk 176-190.

M u u k, Elmar 1933. Väike õigekeelsus-sõnaraamat. Teine trükk. Tartu.

$\mathrm{P}$ a j u s a l u, Karl 2014. Eesti keele sõnaprosoodia lõuna-läänemeresoome taustal. - Keel ja Kirjandus, nr 8-9, lk 575-589.

Posti, Lauri 1950. On quantity in Estonian. - Suomalais-Ugrilaisen Seuran Aikakauskirja, kd 54, nr 2, lk 1-14.

Ravila, Paavo 1961. Kvantiteetti distinktiivisenä tekijänä. - Virittäjä, nr 4, lk 345-350.

Veske, Mihkel 1879. Eesti keele healte õpetus ja kirjutuse wiis. Tartu: Schnakenburg.

V õ r k, Leho 1966. Viron kielen ääntämys. (Studia Philologica Jyväskyläensia II.) Jyväskylä.

V õ r k, Leho 1972. Viron kielen ääntämys. 2. painos. (Studia Philologica Jyväskyläensia II.) Jyväskylä.

Väike õigekeelsuse sõnaraamat. Eesti NSV Teaduste Akadeemia Keele ja Kirjanduse Instituut. Tallinn: Eesti Riiklik Kirjastus, 1953.

W i e d e m a n n, Ferdinand Johann 1875. Grammatik der ehstnischen Sprache, zunächst wie sie in Mittelehstland gesprochen wird, mit Berücksichtigung der anderen Dialekte. St.-Pétersbourg.

\section{Mechanics of the erroneous theory of three distinctive quantities in Estonian}

Keywords: Estonian prosody, phonological models, segmental and syllabic quantity, quantity as a function of syllable, foot

In his paper „Estonian word prosody in the Southern Finnic context” (Keel ja Kirjandus 2014, No. 8-9, pp. 575-589) Karl Pajusalu has recently analysed the prosodic differences and peculiarities of North Estonian, Votic, Livonian and South Estonian. In both North and South Estonian, Pajusalu prefers the concepts of foot and foot isochrony as the most adequate model of Estonian word prosody. However, there are many unsolved problems connected with the calculation of the duration ratio of the first and second syllables of a word. Pajusalu's paper and a lot of research conducted during the last decades fail to pay due attention to the methods of phonological analysis used and results obtained in the 1960s -1990 s. The most important achievement in the research of Estonian prosody in the years mentioned was the abandoning of the concept of three phonological degrees of quantity in Estonian and a re-establishment of the stressed syllable in its rights as the main domain of phonologically relevant quantity characteristics. Pajusalu's paper reflects these developments rather poorly. Pajusalu (and, earlier, Ilse Lehiste) constructs three contrasting word quantities using the position of a syllable-initial consonant as the first quantity degree, although in this position no quantity contrast is possible. This should be taken into account when counting the quantity degrees in Estonian words.

Mati Hint (b. 1937), PhD, Professor Emeritus of Tallinn University 